\title{
Rear-facing camera: Cell phone cinematography in Midnight Traveler (Hassan Fazili, 2019)
}

Miche Dreiling

DOI: $10.15664 /$ fcj.v18i1.2257

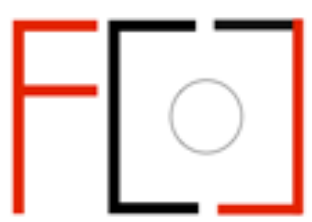

Frames Cinema Journal ISSN 2053-8812

Issue 18 (Jun 2021)

http://www.framescinemajournal.com

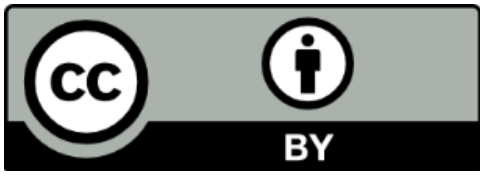




\title{
Rear-facing camera: Cell phone cinematography in Midnight Traveler (Hassan Fazili, 2019)
}

\author{
Miche Dreiling
}

"The camera is an instrument that teaches people how to see without a camera,"

$$
\text { -Dorothea Lange }{ }^{1}
$$

This article explores the aesthetic potentiality of handheld documentary cinematic techniques, including use of the smartphone camera, in a transnational context. Approaching the topic from a transnational perspective supported by functional cinematographic analysis, I explore one case of documentary cinema: Midnight Traveler. ${ }^{2,3}$ As cell phone camera quality has increased and the diffusion of capable devices has widened, cell phone footage has increasingly been incorporated into modern storytelling. ${ }^{4}$ The caveat is that cell phones are largely considered lowtech and amateurish as filmmaking tools in Hollywood-influenced industry contexts. Despite this standard, films like Tangerine (2015), Unsane (2018), and Searching for Sugar Man (2012) have been held up as credible examples of cell phone-shot movies. ${ }^{5}$ I find three salient functions of cell phone camera movement in the cinematography of Midnight Traveler: focalization, reflexivity, and orientation. These functions create intimacy between the audience and subjectcinematographers, spatially orient the viewer, and encourage empathy which can have implications for social change. The cell phone becomes a companion and lifeline to the subjects; its camera/operator intimately guides the viewer's gaze as it captures their journey.

Midnight Traveler tells a story of the Fazili family: Hassan, Fatima (Hossaini), Nargis, and Zahra. Hassan and Fatima are both filmmakers and married, and after the threat to Hassan's life for exposing Taliban leaders in his documentary work, they flee their home in Afghanistan with 
their two young daughters, seeking refuge in neighbouring Tajikistan. The story begins when their paperwork is rejected by Tajikistan authorities, and they are forced to travel in search of safety. The family are cinematographers of their own journey, with all family members holding a phone camera at various points throughout the film.

The case of Midnight Traveler provides an interesting and uniquely global contextual lens through which to view its cinematographic functions, since its production was influenced by a variety of cultures and countries of origin - including the U.S., Qatar, United Kingdom, and Canada -- and was filmed in Afghanistan, Hungary, Turkey, Bulgaria, Serbia, and Iran. Though the film was released in 2019, from a Hollywood-influenced western perspective the cinematographic technology used is commonly considered outdated and/or amateur compared to typical filmmaking equipment (i.e. a high-definition digital cinema camera, various lenses, standapart microphone(s), stabilizers, etc.). Despite utilising equipment not conventionally considered at the fore of modern filmmaking (handheld cell phone cameras), this film has resonated with viewers - winning awards and enjoying a measure of critical success. ${ }^{6}$

In this featurette, I highlight the imperialist and class-based patriarchal implications of the stigma around films shot on cell phones, to "rethink what it is to bear witness to brutality in the age of fundamentally camera-mediated mass self-publication." 7 Through handheld cinematographic movement, the Fazili family tell their story from their perspective. This point of view visually captures their progressive ethos and builds empathy - a critical component for social change. This aesthetic, similar to a feminist documentary approach, is characterised by "biography, simplicity, [and] trust." 8 The crux of the political aim here is liberation - filmmaking provides a window into the lives of those seeking freedom from hierarchically-imposed restrictions. Midnight Traveler, like the feminist political documentaries described by Julia Lesage, is made using simple 
and unimposing equipment, relying on trust between filmmaker and those filmed, and focusing on the lived experiences of human beings. These characteristics generally result in films which have great potential to build empathy for and further the political aims of the filmmakers. ${ }^{9}$

Cell phone-shot films are a prime example of technological democratisation resulting in greater access and more varied representation of perspectives. Media scholars have long theorised the tension between high and low culture that accompanies technological democratisation. ${ }^{10}$ When a technology becomes accessible to more people, its products cease to indicate high cultural value. Consider for example the cultural weight of auteur cinema, literature, and fine art compared to documentary filmmaking, citizen journalism, and folk art, and the divide based on class and access is apparent. When considering intersections of class with nationality and gender, Chandra Mohanty's multi-generational work uses feminist and anti-colonial discourses to identify the capitalist roots of the cultural devaluation of accessible technology. ${ }^{11}$ There is much more to say about strengthening connections between transnational feminist anti-capitalist aims but for our purposes here, it is sufficient to say that they are contextually relevant to the analysis of Midnight Traveler. ${ }^{12}$

Beginning in 1996, the Taliban "decreed that moving pictures were heretical and had to be destroyed." 13 The existential threat to nationally produced Afghan cinema is central to the context of Midnight Traveler's production. ${ }^{14}$ The film industry and creative cinema of Afghanistan are therefore precious during this twenty-first century rebuilding period, and since Hassan and Fatima are both Afghani filmmakers and owners of Kabul's Art Cafe and Restaurant (a progressive cultural venue raided by police in 2014), they must know this on a more intimate and personal level than most. ${ }^{15}$ Though the focus of the film is familial, the Fazilis' social position as cultural influencers is important for understanding how the urgency of their departure displayed in the film 
could be indicative of threats posed to publicly and politically progressive artists, thinkers, and media creators, even in post-Taliban-controlled Afghanistan.

\section{Functions of movement}

Cultural media scholar Jakob Isak Nielsen enumerates the functions of camera movement as orientation, pacing, inflection, reflexive, abstract, and focalization. ${ }^{16}$ This framework for understanding the functions of camera movement, though theorised in reference to narrative cinema, provides a succinct and useful lens for this analysis of documentary cinema. Nielsen defines focalization as "associating the movement of the camera with the viewpoints of characters or entities in the story world." ${ }^{\prime 17}$ This is a primary function of camera movement in Midnight Traveler. The camera moves in much the same way as it would in a home movie, or according to our own sense of sight - it goes where the action is. Throughout the film, the viewer begins to differentiate between the camera operators. At first this is based deductively on who is not pictured in the frame; later, we get to know the way each family member moves the camera based on the rapidness with which the camera pans, the length of the shots, and the direction from which it is moving. The difference between the measured, comparatively steady hands and eyes of the parents and the rapid, jerking, excited hands of the daughters is most evident. The effect of this focalization is that the viewpoints of the characters - and by extension, their characterisations in the film become distinct. To the viewer, this cultivates a deep sense of familiarity with the characters. This is deeper than the familiarity engendered by a typical film because rather than getting to know a person by watching them move on screen, we are being moved by the person - our very gaze directed by them, as if we are seeing the world through their eyes. 
Reflexivity refers to the direction of focus back onto the subject. The reflexive function of camera movement encourages viewers to engage with the camera itself. This is first done explicitly, with Hassan showing his older daughter Nargis "our film camera" - an Android phone.

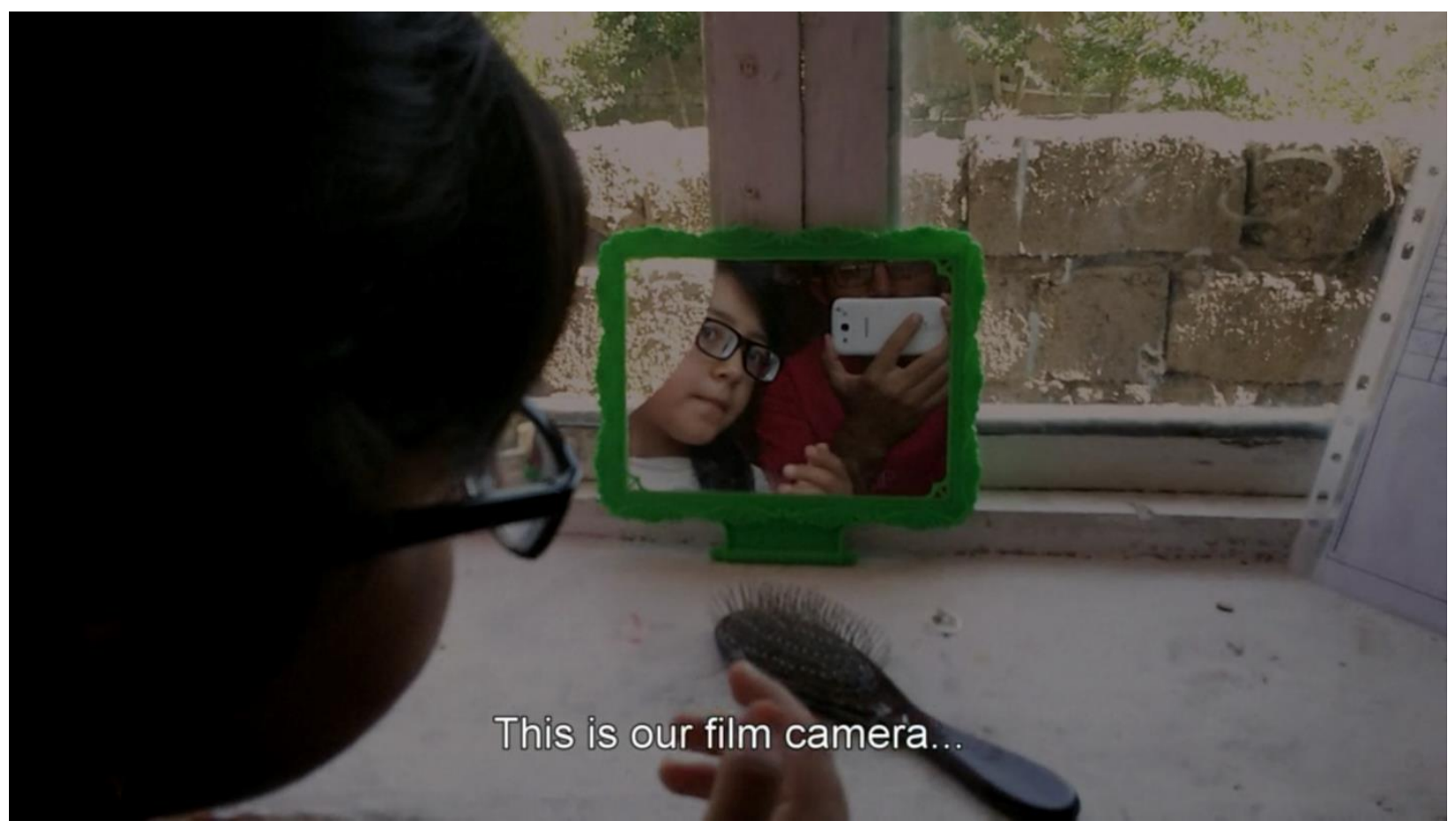

Figure 1: The camera itself is exposed as a reflexive subject for the first time.

A shot follows her excitement to the mirror and shows the phone for the first time as it is filming from Hassan's hand. After this expository segment of the film, the reflexive function of camera movement is less obvious, but the phone of which it is part itself features heavily. For the most part, the family is on an off-road, on foot journey: the phone is shown being used not only as a recording device, but as a map, compass, GPS, and sometimes a mirror for plucking eyebrows, a music player, television and entertainment device for the kids. These functions illuminate the phone as a companion and lifeline rather than simply a device for capturing footage. This makes the process of capturing footage more personal than it would be with, say, an intrusive highdefinition camera and gear setup. The reflexive nature of the camera is also highlighted in several moments when an individual asks not to be filmed, usually during a particularly dangerous or 
emotional part of the journey. The voyeuristic nature of cinema is immediately palpable. The viewer is seeing another human being that does not want to be seen in that moment, yet the viewer is not in control of the device; thus, awareness of the device is heightened in that moment of discomfort, challenging the basic assumptions of capitalistic filmmaking. ${ }^{18}$

Another paradigmatic example of the reflexive nature of camera movement is in an absence of first-hand footage in conjunction with narrative audio that was recorded post facto. In this scene at 1:12:57, we see footage from a generic perspective without human subjects that helps the viewer visualise abstract ideas and concepts while Hassan narrates an experience for which they have no footage: the night their youngest daughter Zahra went missing. Hassan recounts how, as he is searching the woods frantically for his daughter, the thought pops into his mind, "what a scene you're in," both referring to the film they are collaboratively making and also how the experiences they are having will eventually become scenes in the film.

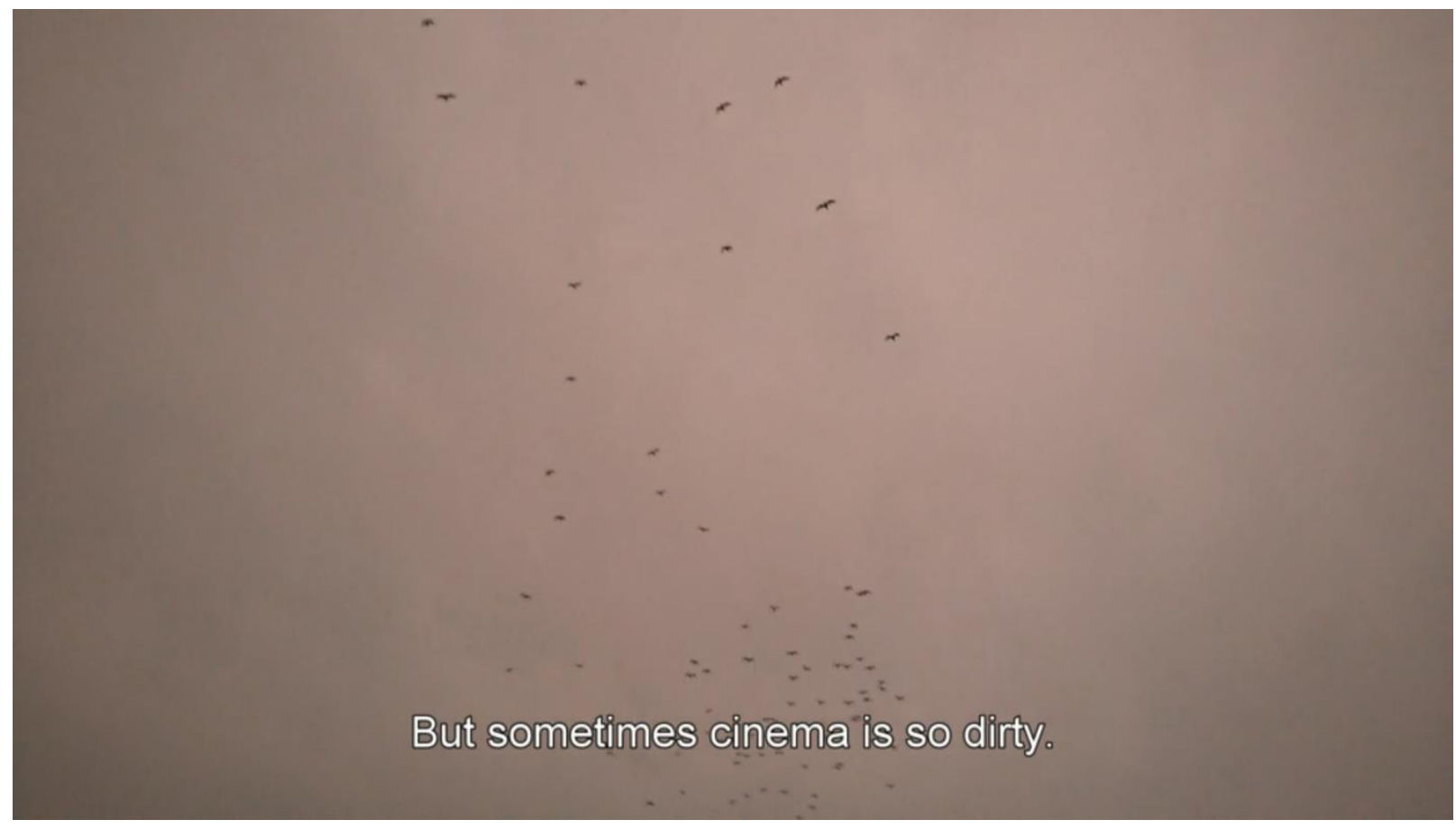

Figure 2: Footage without subjects helps us visualise the experience that Hassan is describing. 


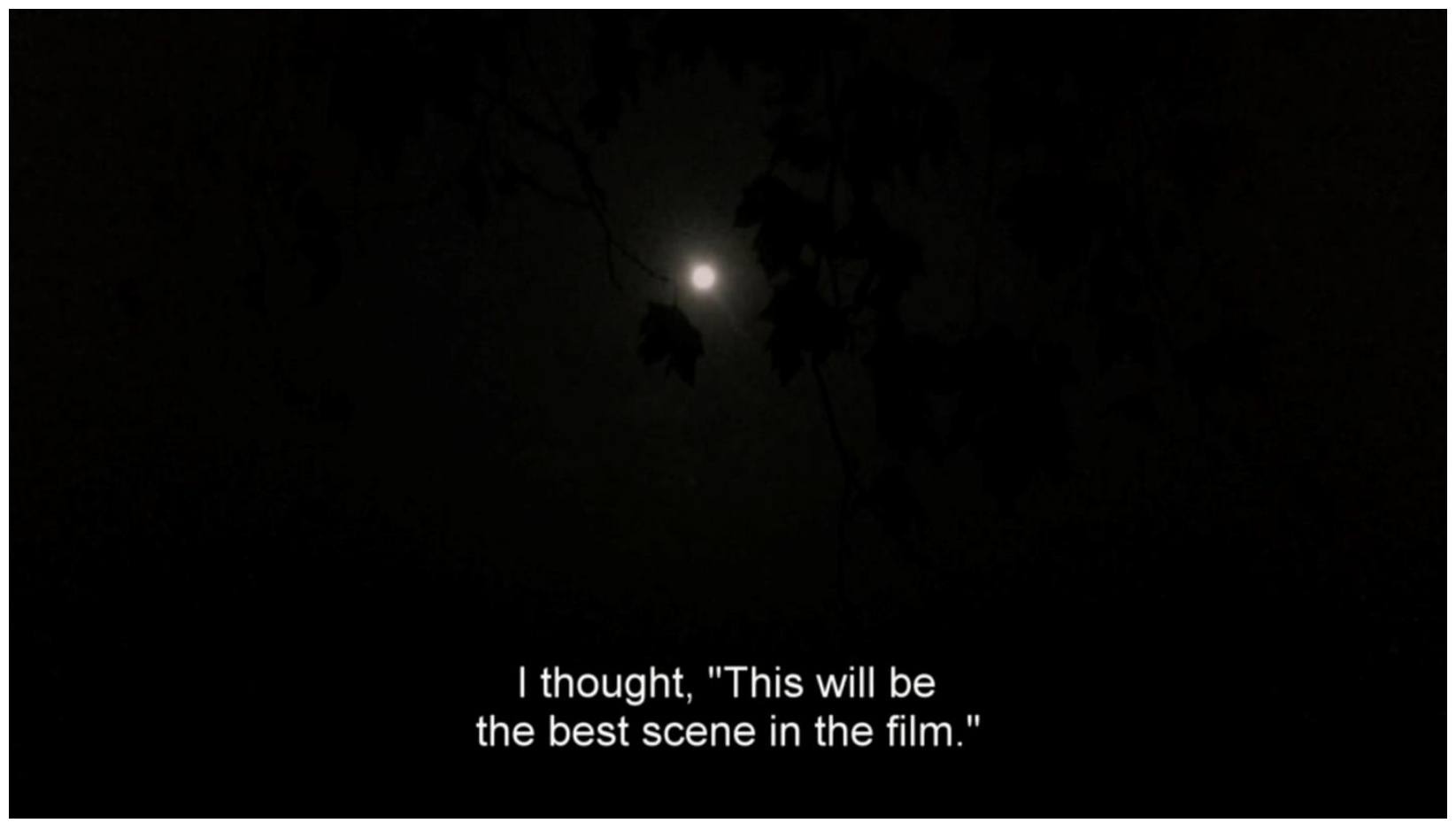

Figure 3: In the absence of footage from the experience we are keenly aware of the lack of camera/sight.

He recounts thinking that maybe he should turn on the camera while he looked for Zahra, but a visualisation of him finding his daughter in distress and his wife seeing him filming that moment brought him to tears. "I hated myself so much. I hated cinema. I couldn't do it," he said. Through this reflection, the viewer is forced to consider the Fazilis' experience as cinematographers of their own experience: a meta-reflexive endeavour encouraging empathy in the viewer and deepening the connection between audience and subject.

The last major function of camera movement within Midnight Traveler concerns the spatial orientation of the viewer. As a film about a journey, it makes sense that orientation would be crucial. There are moments when the camera moves to show the map and to capture conversations about navigating upcoming terrain. These movements function to orient the viewer geographically and topographically. Beyond these overt moments, there are also subtle ways in which the camera moves and is moved that orient the viewer. For example, there are multiple scenes when the family 
is in a car. Sometimes these scenes are shot during the day, sometimes night, when the darkness seems to make the very real danger they are facing yet more ominous. More than that, during the car scenes, the camera moves with the bumps in the road. The camera movement coincides with the audio of the various older cars' metal clanging as they hit potholes, giving the viewer a sense of being in the car, looking out the window, sharing the journey of the Fazilis.

\section{Meaning-making}

The resulting meanings that are constructed by the functions and effects of camera movement described above can be elucidated through contextualisation within the story being documented. Camera movement in Midnight Traveler functions to focalize Hassan, Fatima, Nargis, and Zahra Fazili through familial connection and intimate collaboration, resulting in a deep connection between the viewer and subjects. I would expand "subjects" to include the camera itself; the reflexivity created through calling attention to the camera as an entity serves to establish it as a non-human actor and companion, a position not without theoretical precedent in media studies. ${ }^{19}$ Midnight Traveler represents international conflict alongside interpersonal and familial tension and care. Through their cinematography, the Fazili family capture not only their progressive ideals explicitly on camera, but the implicit results of holding such ideals publicly. In a globalized context in which their national film industry and legacy had been recently threatened by extremists, these filmmakers took action that kept their family safe and produced a film that mattered in telling their story, quite literally, from their point of view. Empathy is often advocated as foundational to democracy and social change, and for good reason. Midnight Traveler is one case that shows through cinematographic techniques and reflexive filmmaking, empathy can naturally follow. 


\section{Notes}

1. Robert Kirsch, "Dorothea Lange: The Photographer Who showed Americans how to See Themselves: Photographer Who Helped America See itself," Los Angeles Times, Aug 13, 1978, N1.

2. Hassan Fazili, dir. Midnight Traveler. 2019; Old Chilly Pictures.

3. This film was released in the UK using the spelling "Traveller," but because it was produced in the U.S. and distributed elsewhere using the original spelling, "Traveler" is used here throughout.

4. Daniel Bean. "A Near-Complete History of Movies and TV Shows Shot on Smartphones." The Observer. March 29, 2019; Kate Erbland. "11 Movies Shot on iPhones, From 'Tangerine' to a Charming Short By Michel Gondry." March 22, 2018; Marta Falconi. "Documentary Shot with Cell Phone Camera." NBCNews.com. June 14, 2006.

5. Jourdan Arnaud, "5 Films Shot with a Smartphone." The Los Angeles Film School. September 9, 2020.

6. Manohla Dargis, "Midnight Traveler' Review: A Refugee Family's Search for Safe Harbor." The New York Times. September 17, 2019; IMDb, "Midnight Traveler (2019)." IMDb.com. Accessed February 12, 2021; The Society of American Archivists (SAA), "2008 SAA Award Recipients." SAA: Awards Acknowledge Outstanding Achievements. 2008.

7. Kari Andén-Papadopoulos, "Citizen camera-witnessing: Embodied political dissent in the age of 'mediated mass self-communication," "new media \& society 16, no. 5 (2014): 754.

8. Julia Lesage, "The political aesthetics of the feminist documentary film," Quarterly Review of Film \& Video 3, no. 4 (1978): 507-508.

9. Ibid.

10. Dick Hebdige, Subculture: The Meaning of Style. New York: Routledge, 1979: Walter Benjamin, The work of art in the age of mechanical reproduction. Penguin UK, 2008.

11. Chandra Mohanty, "Under Western eyes: Feminist scholarship and colonial discourses." Feminist review 30, no. 1 (1988): 61-88; Chandra Talpade Mohanty, "“Under western eyes" revisited: Feminist solidarity through anticapitalist struggles." Signs: Journal of Women in culture and Society 28, no. 2 (2003): 499-535.

12. For further reading, see Davis, The meaning of freedom, 2012; McCabe, Race, 65, 2004; Ponzanesi, Postcolonial, 25, 2017, and Jaikumar, Feminist, 205, 2017.

13. Erlend Clouston, "If I find one reel, I must kill you." The Guardian, February 19, 2008. 14. The Society of American Archivists (SAA), 2008; Clouston, The Guardian, 2008.

15. Pamela Constable, "Kabul Cafe Is a Front Line in a War over Culture and Social Mores in Afghanistan." The Washington Post. WP Company, August 16, 2014.

16. Jakob Isak Nielsen, Camera Movement in Narrative Cinema-Towards a Taxonomy of Functions. 2007; Jakob Isak Nielsen, "Five Functions of Camera Movement in Narrative Cinema," in Transnational Cinematography Studies. United States: Lexington Books, 2016. 17. Nielsen, 2007, 220.

18. Laura Mulvey, "Visual pleasure and narrative cinema," in Visual and other pleasures. Springer, 1989.

19. Bruno Latour, "On actor-network theory: A few clarifications." Soziale welt (1996): 369-381. 


\section{Bibliography}

Andén-Papadopoulos, Kari. "Citizen camera-witnessing: Embodied political dissent in the age of 'mediated mass self-communication." new media \& society 16, no. 5 (2014): 753-769.

Arnaud, Jourdan. "5 Films Shot with a Smartphone." The Los Angeles Film School. September 9, 2020. https://www.lafilm.edu/blog/5-films-shot-with-a-smartphone/.

Bean, Daniel. "A Near-Complete History of Movies and TV Shows Shot on Smartphones.” The Observer. March 29, 2019. https://observer.com/2019/03/smartphone-filmmakingmovies-tv-music-videos-shot-camera-phones/.

Benjamin, Walter. The work of art in the age of mechanical reproduction. Penguin UK, 2008.

Clouston, Erlend. "If I find one reel, I must kill you.” The Guardian, February 19, 2008. https://www.theguardian.com/film/2008/feb/20/features.afghanistan.

Constable, Pamela. "Kabul Cafe Is a Front Line in a War over Culture and Social Mores in Afghanistan." The Washington Post. WP Company, August 16, 2014. https://www.washingtonpost.com/world/asia_pacific/kabul-cafe-is-a-front-line-in-a-warover-culture-and-social-mores-in-afghanistan/2014/08/14/5d72f972-23b5-11e4-8b107db129976abb_story.html.

Dargis, Manohla. “'Midnight Traveler' Review: A Refugee Family's Search for Safe Harbor." The New York Times. September 17, 2019. https://www.nytimes.com/2019/09/17/movies/midnight-traveler-review.html.

Davis, Angela Y. The meaning of freedom: And other difficult dialogues. City Lights Publishers, 2012.

Erbland, Kate. "11 Movies Shot on IPhones, From 'Tangerine' to a Charming Short By Michel Gondry." March 22, 2018. https://www.indiewire.com/2018/03/movies-shot-on-iphonesunsane-tangerine-shorts-1201941565/.

Falconi, Marta. "Documentary Shot with Cell Phone Camera." NBCNews.com. June 14, 2006. https://www.nbcnews.com/id/wbna13325356.

Fazili, Hassan, dir. Midnight Traveler. 2019; Old Chilly Pictures. Amazon Prime via Oscilloscope; https://www.amazon.com/Midnight-Traveler-HassanFazili/dp/B0811B6YH5/ref=sr_1_1?dchild=1\&keywords=midnight + traveler\&qid=16224 92325\&s=instant-video\&sr=1-1

Hebdige, Dick. Subculture: The Meaning of Style. New York: Routledge, 1979. 
IMDb. “Midnight Traveler (2019).” IMDb.com. Accessed February 12, 2021. https://pro.imdb.com/title/tt8923500/details.

Jaikumar, Priya. "Feminist and non-western interrogations of film authorship," in Hole, Kristin Lené, Dijana Jelača, E. Ann Kaplan, and Patrice Petro, eds. The Routledge Companion to Cinema \& Gender. Taylor \& Francis, 2017. 205-214.

Kirsch, Robert. "Dorothea Lange: The Photographer Who showed Americans how to See Themselves: Photographer Who Helped America See itself." Los Angeles Times (19231995), Aug 13, 1978. N1. ProQuest Historical Newspapers.

Latour, Bruno. "On actor-network theory: A few clarifications." Soziale welt (1996): 369-381.

Lesage, Julia. "The political aesthetics of the feminist documentary film." Quarterly Review of Film \& Video 3, no. 4 (1978): 507-523.

McCabe, Janet. "Race, ethnicity, and post-colonialism/modernism," in Feminist film studies: Writing the woman into cinema. Wallflower Press, 2004.

Mohanty, Chandra Talpade. "“Under western eyes" revisited: Feminist solidarity through anticapitalist struggles." Signs: Journal of Women in culture and Society 28, no. 2 (2003): 499-535.

Mohanty, Chandra. "Under Western eyes: Feminist scholarship and colonial discourses." Feminist review 30, no. 1 (1988): 61-88.

Mulvey, Laura. Visual and other pleasures. Springer, 1989.

Ponzanesi, Sandra. "Postcolonial and transnational approaches to film and feminism," in Hole, Kristin Lené, Dijana Jelača, E. Ann Kaplan, and Patrice Petro, eds. The Routledge Companion to Cinema \& Gender. Taylor \& Francis, 2017. 25-35.

The Society of American Archivists (SAA). "2008 SAA Award Recipients." SAA: Awards Acknowledge Outstanding Achievements. 2008. http://www.archivists.org/recognition/sanfrancisco2008-awards.asp\#spotlight.

\section{Author Biography}

Miche Dreiling is a doctoral candidate in Media Studies with a certificate in Women, Gender, and Sexuality Studies at the University of Oregon. Miche is a scholar-filmmaker whose research and creative work explores social constructions of identity and portrayals in media, queer theory and praxis, and intersectional solidarity. Their current work focuses on nonbinary gender as a medium of communication using documentary filmmaking and collaborative ethnographic methods. Previous work has centred on themes of transitioning, labour organizing, adoption, trauma, and 
food insecurity. In moments outside of academia, they enjoy spending time with family and in creative pursuit. In order to live on a graduate wage in the United States, they teach courses as an adjunct, work as a freelance video producer, and market handmade wares that they create from repurposed materials. 